\title{
红色旅游传承红色记忆的理论逻辑与动态过程
}

\author{
李卫飞,方世敏, 阎友兵,马丽君
}

(湘潭大学, 湘潭 411105)

\begin{abstract}
摘要: 红色旅游在传承红色记忆方面发挥着重要作用,但对红色旅游为什么能够传承红色记 忆, 以及红色旅游传承红色记忆的具体过程等基础问题尚缺乏深人的理论探讨。以文化记忆 理论和互动仪式链理论为依据, 论证了红色记忆作为文化记忆、红色旅游作为仪式的理论合理 性,明确了红色记忆传承的基本规律,提出了红色旅游传承红色记忆的理论逻辑和动态过程模 型, 并进一步讨论了红色旅游作为一种仪式在传承红色记忆方面的独特价值、作用边界、融合 发展和实践路径等问题。研究结论有助于红色旅游理论研究者从更普适性的视角和更深的理 论层次认识红色旅游与红色记忆之间的关系, 为实践领域更好地开展红色旅游工作提供了基 础理论支持。
\end{abstract}

关键词：红色记忆;红色旅游;文化记忆;互动仪式

红色记忆在巩固中国共产党执政基础、强化政权合法性建设、建构身份认同等方面 发挥着重要的作用 ${ }^{[1,2]}$ 。但随着时间流失、技术主义和历史虚无主义的侵蚀，红色记忆在 不同程度上遭到弱化与冲击 ${ }^{[2,3]}$ 。为了应对红色记忆的淡化问题，党和国家的宣传部门采 取了多种方式、方法，传递、唤起和巩固红色记忆。在众多的方式、方法中，红色旅游 以一种创新的模式，在传递、唤起和巩固红色记忆中发挥的作用越来越明显 ${ }^{[4-9]}$ 。但与红 色旅游在实践领域发挥越来越明显作用不一致的是，阐释红色旅游传承红色记忆的基础 理论研究仍然薄弱，红色旅游为什么能够传递、唤起和巩固红色记忆? 红色旅游传递、 唤起和巩固红色记忆的过程是什么? 对上述问题还缺乏深人的理论探讨，学术界对红色 旅游传承红色文化的认识尚处于 “知其然，而不知其所有然” 的状态。本文尝试运用文 化记忆理论和互动仪式链理论，构建红色旅游传承红色记忆的理论逻辑和动态过程理论 框架，在建构理论框架的基础上，进一步对红色旅游与红色文化之间的关系进行讨论， 以期为 “红色旅游传承红色记忆” 提供理论指导。

\section{1 作为文化记忆的红色记忆}

红色记忆作为红色文化的重要组成部分，凝聚着党的优良作风和光荣传统，是党的 重要精神资源 ${ }^{[10,11]}$ ，是对中国共产党所领导的革命历史与革命文化的记忆建构与意象展 现 ${ }^{[12]}$ 。红色记忆传输着稳定的内容和意义储备，具有 “神圣性” 的特征 ${ }^{[13]}$ 。当前学术界 普遍认为红色记忆属于集体记忆 ${ }^{[2,14-17]}$ ，但从记忆研究的相关理论来看 ${ }^{[18]}$, 将红色记忆归 属于文化记忆的范畴更加科学和准确，也将为红色记忆研究拓展更大的理论空间。

收稿日期：2021-02-08; 修订日期：2021-08-08

基金项目：国家自然科学基金项目（71904146）；湖南省社会科学基金项目（16YBQ065）

作者简介：李卫飞（1987- ), 男, 河南㚘县人, 博士, 讲师, 研究方向为休闲与社会发展。E-mail: feiweili@163.com 


\section{1 集体记忆与文化记忆}

文化记忆理论承接于集体记忆理论 ${ }^{[19,20]}$ ，奥斯曼 ${ }^{[2]}$ 首先区分了以日常交流为基础的集 体记忆（交际记忆）和以充满象征的文化具体化为基础的集体记忆（文化记忆）之间的 巨大差异，交际记忆因日常互动而产生，以同时代人的历史经验为内容，其内容是可变 的，未被赋予固定的意义，每个人都被视为有能力回忆、解释共同过去; 与之相反，文 化记忆涉及的这种记忆, 与稳定的客观性相关, 具有高度建构性, 业已被仪式化, 在节 庆的文化时间维度中被唤起，其对象是来自过去的、神秘的、被阐释为具有集体创建性 的事件, 文化记忆传输着稳定的内容和意义储备, 为了使其得以延续, 为了能够对其进 行阐释，人们需要培养专门的人才 ${ }^{[22]}$ 。奥斯曼 ${ }^{[2]}$ 将文化记忆界定为 “所有通过一个社会 的互动框架指导行为和经验的知识”。文化记忆理论的优势在于：一方面，文化记忆理论 深度揭示了人类文明传承的内在逻辑; 另一方面，文化记忆所具有的时间维度、功能维 度、媒介维度、权力维度和建构维度进一步丰富和深化了记忆理论研究 ${ }^{[1,20,23,24]}$ 。

\section{2 将红色记忆作为文化记忆的合理性}

判断一种记忆是否属于文化记忆，需要从文化记忆的一系列核心特征出发。因此红 色记忆是属于集体记忆还是属于文化记忆，可以从文化记忆所包含的核心特征进行识 别。表 1 详细描述了文化记忆的时间特征、功能特征、媒介特征、权力特征和建构特 征，同时对红色记忆所具有的文化记忆特征的具体表现进行了分析。对比分析的结果显 示：（1）红色记忆依靠象征革命意义的红色符号进行传递 ${ }^{[13]}$, 这与文化记忆 “依靠符号 传承，与当下相关联，并指向未来” 相一致;（2）红色记忆蕴含在红色纪念空间、红色 图形、革命历史剧、红色歌谣之中，这与文化记忆的媒介特征相一致;（3）红色记忆在 凝聚共识、达成集体认同、政党认同等方面具有显著的作用，与文化记忆的核心功能 “为群体提供身份认同 ${ }^{[30]}$, 并为当下提供合法性” 相一致。总的来看，红色记忆的符号传 播特征、媒介特征、构建身份认同与政权合法性特征、与政治权力的密切关系、高度的 社会建构性，都表明了红色记忆是一种典型的文化记忆。

\section{3 将红色记忆作为文化记忆的理论优势}

尽管将红色记忆归属于集体记忆具有其合理性，但从红色记忆所具有的文化记忆特 征来看, 将红色记忆归属为文化记忆更加科学合理。更为重要的是, 从基础理论研究视 角来看, 将红色记忆归属为文化记忆, 将使红色记忆理论研究获取更大的理论优势。这 些理论优势集中表现在两个方面：一是，文化记忆理论相较于集体记忆理论本身更具优 势, 文化记忆详细论述了记忆所具备的文化和社会功能, 对记忆形成的具体过程以及各 种社会因素对记忆的塑造和影响进行了充分论证 ${ }^{[18]}$ ，以文化记忆理论指导红色记忆的理 论研究, 将使红色记忆理论研究具有更强的理论生命力; 二是, 文化记忆丰富的理论内 涵和详尽的理论细节，为红色记忆的理论研究提供了广阔的理论空间，关于文化记忆的 建构过程、传承规律、传承路径，文化记忆理论都进行了详细的阐述 ${ }^{[19,21,31]}$, 这些理论细 节为我们应对红色记忆淡化问题提供了理论和方法指导。

\section{2 红色旅游传承红色记忆的理论逻辑}

文化记忆是借助 “文本系统、意象系统、仪式系统” 等文化符号传承的，这些 “文 本系统、意象系统、仪式系统” 就是记忆的媒介，文化记忆的内容只有借助媒介才能过 


\section{表 1 红色记忆具有文化记忆特征的具体表现}

Table 1 The manifestation of red cultural memory characteristics

文化记忆的特征 ${ }^{[19,21]}$
- 时间特征：主要表现在文化记忆的时间跨度
比交际记忆更大, 因此需要依靠符号来传承, 它
与当下相关联, 并指向未来

- 媒介特征：文化记忆依靠文本系统、意象系 统、仪式系统等文化符号来传承, 由软记忆和硬 记忆来承载

- 功能特征: 文化记忆的核心功能是为群体提 供身份认同, 并为当下提供合法性

- 权力特征：记忆背后的权力逻辑决定了哪些 过去的记忆可以进人文化记忆的, 哪些记忆不能 进人文化记忆

- 建构特征：文化记忆是一种追溯性的结构, 在权力逻辑的指引下, 由社会群体建构而成
红色记忆在文化记忆特征上的具体表现

- 红色记忆很大程度上已经成为了一种精神现象和政治现

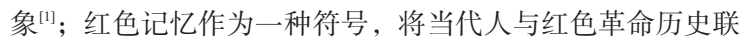
系在一起 ${ }^{[13,25]}$, 并为当代人如何看待过去、现在和未来指明 了方向 ${ }^{[2]}$

- 红色记忆媒介特征体现在红色纪念空间 ${ }^{[1]}$ 、红色图形 ${ }^{[26]}$

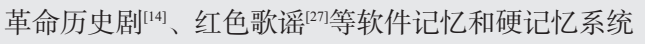

- 红色记忆在凝聚共识、达成集体认同、政党认同等方面 具有显著的作用 ${ }^{[14,28,29]}$; 红色记忆是是对当前和未来国家政治 合法性认同的共同价值基础 ${ }^{[15]}$

- 政权合法性建设导致红色记忆大规模涌现 ${ }^{[1]}$, 红色记忆再 生产本质上属于政治行为, 红色记忆的再生产必须依循国家 政党意志 ${ }^{[16]}$

- 红色记忆是对过去的一种选择性建构, 它既以红色精神 的历史本源为线索, 又被当前社会的关注所形塑 ${ }^{[15]}$

渡和转换成文化层面的记忆, 为个体所分享, 并发挥其作用 ${ }^{[19-21]}$ 。作为文化记忆的红色记 忆的传递、唤起和巩固, 同样需要借助文本系统、意象系统、仪式系统等记忆媒介。那 么作为文化记忆媒介的文本系统、意象系统和仪式系统之间的作用规律是什么? 红色记 忆中的文本系统、意象系统和仪式系统是什么? 红色旅游与文化记忆媒介之间的关系又 是什么? 对上述问题的回答是阐释红色旅游传承红色记忆理论逻辑的关键所在。

\section{1 文本系统、意象系统和仪式系统的作用规律}

根据索绪尔对符号的定义，符号是由能指和所指所构成的符号形式与符号内容的二 元关系, 即一个符号本身就包含了能指、所指以及能指和所指之间的关系, 符号通过符 号的阐释过程发挥作用 ${ }^{[32]}$ 。那么作为文化符号的文本系统、意象系统和仪式系统，其媒 介作用过程也应遵循符号作用的基本规律, 文本系统可以理解为符号的能指, 意象系统 可以理解为符号的所指和将能指和所指匹配起来的规则 (代码), 仪式系统可以理解为一 系列具体的符号阐释过程。如此以来，文化记忆的文本系统就包括各种物质和非物质的 符号体, 这些物质和非物质的符号体在文化记忆中被称为硬记忆 (广场、纪念碑、雕塑 等）和软记忆（文学作品、历史叙述等） ${ }^{[33]}$; 文化记忆的意象系统则包括上述硬记忆和 软记忆所指向的社会建构物（民族情感、价值观、身份认同等精神文化）以及将硬记忆 和软记忆与社会建构物相匹配的规则; 但无论是文本系统还是意象系统都无法自动发生 关联, 这需要有专门的阐释活动, 而仪式系统就是一系列阐释活动的综合 ${ }^{[32]}$ 。由此可 见, 在文化记忆的传承过程中, 必须借助仪式系统, 才能将文本系统和意象系统连接起 来。总的来看, 借助仪式这一手段, 在群体中传递文本所指向的意象是文化记忆得以传 承的内在逻辑。

\section{2 红色记忆“文本系统、意象系统、仪式系统”的具体内容}

根据对文化记忆文本系统、意象系统和仪式系统的解释, 作为文化记忆的红色记 忆, 其文本系统、意象系统和仪式系统的具体所指包括：以近现代以来，由中国共产党 领导的重大事件、重大活动和重要人物事迹等历史文化遗存为代表的文本系统, 具体表 


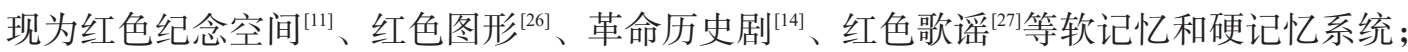
以红色文化、红色基因等革命精神为代表的意象系统, 具体表现为红船精神、井冈山精 神、苏区精神、长征精神等 ${ }^{[15]}$; 以重大节庆活动、纪念活动、日常学习活动、日常参观 瞻仰活动为代表的仪式系统，具体表现为国庆节、劳动节、建党节、建军节等节庆纪念 活动等内容。红色记忆的传递、唤起和巩固同样依靠节庆纪念日等仪式活动，将革命历 史遗存与革命精神相联系 ${ }^{[13]}$ 。

\section{3 仪式系统在红色记忆传承中的独特价值}

从文化记忆的本质来看，文化记忆涉及的这种记忆，与稳定的客观性相关，具有高 度的建构性，文化记忆传输着稳定的内容和意义储备 ${ }^{[22]}$ ，在固定的时间内，文化记忆的 文本系统和意象系统往往是被严格规定的，由于文化记忆的文本系统和意象系统的稳定 性, 在文化记忆的传递、唤起和巩固过程中, 仪式系统的灵活和吸引力就在很大程度上 决定了文化记忆的传承效果，文化记忆的消失与强迫的仪式、空洞的仪式密切相关。就 红色记忆而言，它与中国共产党执政基础和政党认同的密切关系 ${ }^{[1,15,28]}$, 决定了红色记忆 具有高度的政治关联性, 因而红色记忆中的文本系统和意象系统是被官方高度规定的, 从文本的选择到意象的阐释，文本与意象如何关联都需要严格的官方审查，以保证其政 治正确性 ${ }^{[13]}$; 与红色记忆的文本系统和意象系统不同的是，红色记忆的仪式系统具有相 对的灵活性，在规定了文本系统和意象系统的前提下，采取何种仪式来阐释红色记忆的 文本，以达到传承革命精神的目的，官方并未规定，相反，国家鼓励以多种方式、方法 展开红色文化、红色基因的宣传工作。从红色记忆文本系统和意象系统的高度规定性， 以及红色记忆仪式系统的相对灵活性来看, 仪式系统在红色记忆传承中具有独特的价 值，对红色记忆传承效果具有重要影响。

\section{4 红色旅游活动作为一种仪式系统}

红色旅游活动能够传递、唤起和巩固红色记忆是红色旅游研究者的普遍共识 ${ }^{[4-8]}$ ，也 有学者通过实证研究证明了红色旅游活动具有维护中国共产党执政历史合法性的作用 ${ }^{[28]}$, 但这些直观认知和经验证据还不足以确立其理论 “合法性”。确立红色旅游能够传递、唤 起和巩固红色记忆理论合理性的关键是 “确定红色旅游活动属于仪式”，因为根据前文的 理论推演，在文化记忆的传递、唤起和巩固过程中，必须借助仪式系统，才能将文本系

统（能指）和意象系统（所指）连接起来, 实现红色记忆的传承 ${ }^{[13]}$ 。

旅游作为一种仪式的理论 “合法性” 最早在纳尔什・格雷本的“旅游仪式论” 中得 到论述，将旅游视为一种 “世俗仪式” 已经成为旅游人类学研究的经典视角之一 ${ }^{[34-37]}$ 。 红色旅游作为众多旅游活动类型中的一种，尽管其具有一定的特殊性，但其本质仍然是 旅游活动, 因此红色旅游活动也可以被看作一种仪式, 不仅如此, 由于红色旅游资源和 吸引物本身所具有的正式性和严肃性, 红色旅游的仪式性更强 ${ }^{[13,38]}$, 因此将红色旅游活 动视为一种仪式，在理论上具有自洽性。在承认 “红色旅游活动是一种仪式” 的前提 下，根据文化记忆理论关于文化记忆传承规律的描述，红色旅游活动属于红色记忆传承 媒介中的仪式系统, 红色旅游活动 (作为仪式系统的组成部分) 具备传承红色记忆的理 论合理性。

\section{5 红色旅游活动传承红色记忆的理论框架}

综述所述，可以明确以下基本观点：红色记忆属于文化记忆；红色记忆依靠文本系 
统、意象系统和仪式系统三大记忆媒介进行传承; 仪式系统在红色记忆传承中具有独特 价值; 红色旅游活动作为一种仪式，属于红色记忆传承媒介中的仪式系统。将上述基本 结论连接起来, 根据文化记忆理论关于文化记忆传承规律的描述进行推演, 不难发现, 作为仪式系统的红色旅游活动具有传承红色记忆（文化记忆）的理论合理性。将上述分 析结论相联系, 可以推演出红色旅游活动传承红色记忆的理论逻辑, 具体可以概括为如 下观点和理论框架（图 1)。

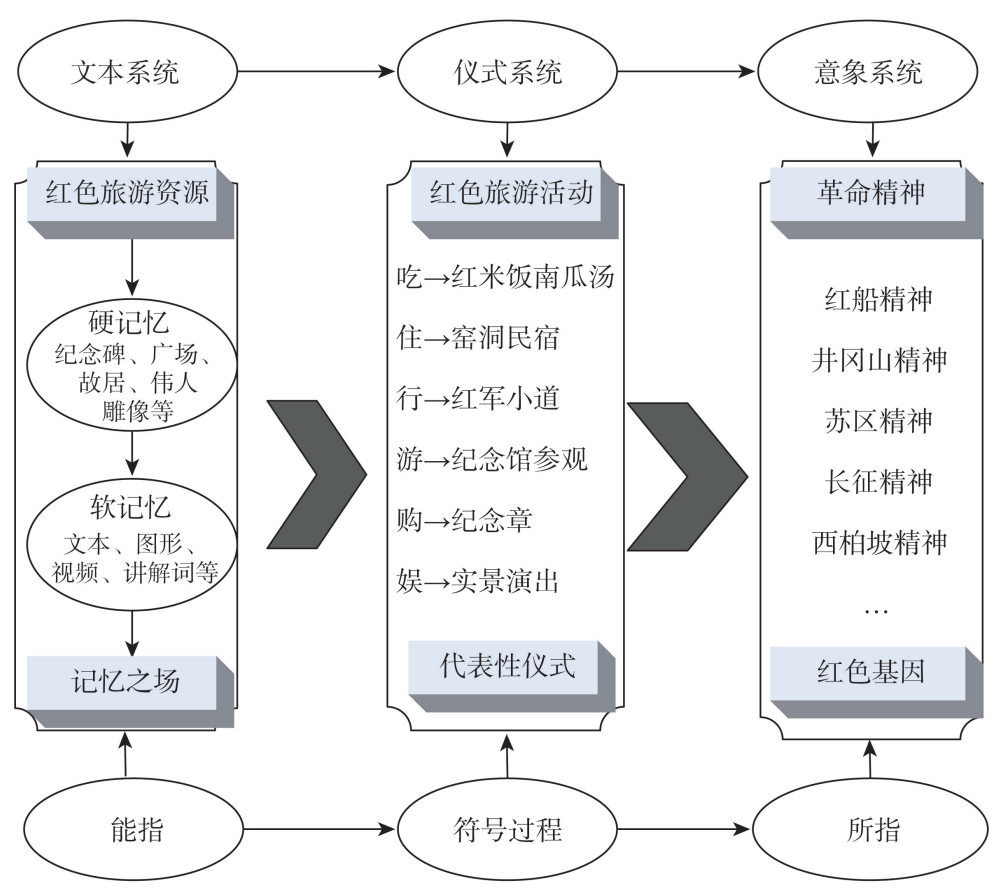

图 1 红色旅游活动传承红色文化记忆的理论逻辑

Fig. 1 The theoretical logic of red tourism inheriting red cultural memory

（1）红色旅游资源构成了红色记忆的文本系统, 这些资源包括纪念碑、广场、故 居、伟人雕像等硬记忆和红色文本、图形、视频、讲解词等软记忆, 硬记忆和软记忆的 组合共同构建了一个 “记忆之场”, 记忆之场是红色记忆被唤起的物质和非物质基础; （2）革命精神和红色基因构成了文化记忆的意象系统, 具体表现为红船精神、井冈山精 神、苏区精神、长征精神等，传承红色记忆的根本目的是革命精神和红色基因的代际传 递; (3) 红色旅游活动作为仪式系统, 具体表现为红色旅游活动中的吃、住、行、游、 购、娱等世俗仪式，借助红色旅游活动的世俗仪式，红色记忆在红色旅游资源构成的 “记忆之场” 中被传递、唤起和巩固；（4）红色旅游传承红色记忆的过程遵循基本的符号 逻辑, 即借助红色旅游仪式 (符号过程), 在群体 (红色旅游游客) 中将红色符号的能指 与所指（革命精神与红色基因）联系起来。

\section{3 红色旅游传承红色记忆的动态过程}

在理论分析中, 本文提出了红色旅游传承红色记忆的理论逻辑, 从理论上阐释了红 色旅游活动作为传承红色记忆方式的理论合理性和实践重要性。在上述逻辑框架内, 为 
了进一步阐释红色旅游活动这一仪式系统在传承红色记忆中的具体作用过程, 引人互动 仪式链理论, 尝试打开红色旅游活动传承红色记忆具体过程的 “黑箱”, 构建红色旅游传 承红色记忆的动态过程模型。

\section{1 作为互动仪式的红色旅游活动}

旅游活动作为一种 “面对面” 的仪式活动, 互动是其重要的活动特征, 因此在旅游 体验研究中, 有必要对这种互动特性进行科学解释 ${ }^{[36]}$, 在红色旅游景区展开的红色旅游 活动, 是典型的 “在场” 行为, 游客的共同在场不可避免地具有互动性, 因此, 红色旅 游活动这一仪式, 更准确地说应该是一种互动仪式 ${ }^{[39]}$ 。柯林斯 ${ }^{[40]}$ 将戈夫曼的互动仪式理论 进行了扩展, 对互动仪式的作用过程进行了详细深人的论述, 并提出了互动仪式链理 论。互动仪式链理论认为在具体的社会情景中发生的互动行为可以看作一种互动仪式, 所有的互动仪式都是 “一个具有因果关联与反馈循环的过程”, 从人们日常生活的对话活 动、体育活动、集会、看电影到严肃的宗教和政治活动都是一条互动仪式链 ${ }^{[41]}$ 。本文认 为, 红色旅游活动是一种典型的互动仪式, 可以借助互动仪式链理论, 对红色旅游活动 传承红色记忆的过程, 进行系统地阐释。

\section{2 互动仪式链的核心机制}

柯林斯 ${ }^{[10]}$ 提出的互动仪式包括四个方面的要素：（1）身体共在，两个或两个以上的 人聚集在同一场所；（2）排除局外人的屏障，仪式情景对外人设定了界限；（3）相互关 注，人们将其注意力集中在共同的对象或活动上，并相互传达该关注点；（4）共享的情 感状态, 人们分享共同的情绪或情感体验。柯林斯 ${ }^{[40]}$ 进一步提出, 互动仪式链的核心机 制是：“高度的相互关注与高度的情感连带, 通过身体的协调一致、相互激起/唤起参加 者的神经系统而结合在一起，进而形成了与认知符号相关联的成员身份感，同时也为每 个参加者带来了情感能量, 使他们感到有信心、热情和愿望去做他们认为道德上容许的 事情”。

\section{3 互动仪式结果与红色记忆传承}

柯林斯 ${ }^{400}$ 认为互动仪式可以产生一系列结果（成功仪式的结果）, 其中主要包括: （1）群体团结, 一种成员身份的感觉; (2) 个体的情感能量, 一种采取行动时的自信、 热忙的感觉;（3）代表群体的符号, 标志或其他的代表物;（4）道德感，维护群体中的 正义感, 尊重群体符号。将互动仪式的主要结果与红色记忆传承要达到的目的进行对 比, 会发现二者存在高度的一致：互动仪式结果中的群体团结与成员身份感, 与红色记 忆得到传承后所实现的身份认同、集体认同相一致; 互动仪式所产生的情感能量, 与红 色记忆被传递、唤起和巩固后所产生的爱国主义、民族情感相一致 ${ }^{[4,8]}$; 互动仪式所产生 的群体符号, 与红色记忆中的英雄人物、伟大事迹、革命精神相一致; 互动仪式所产生 的道德感、维护群体中的正义感，与红色记忆所提供的政权合法性相一致。互动仪式结 果与红色记忆传承之间的密切关系, 表明在红色旅游景区发生成功的互动仪式（红色旅 游活动）能够有效地实现红色记忆的传承。

\section{4 红色旅游活动传承红色记忆的动态过程模型}

在上述分析中, 明确了以下基本问题: 红色旅游活动是一种互动仪式; 互动仪式结 果与红色记忆传承之间关系密切; 互动仪式的核心机制是相互关注和情感连带; 运用互 动仪式链理论阐释红色旅游活动传承红色记忆的动态过程具有理论合理性。在互动仪式 链理论的基础上，根据前文的理论推导，提出如下观点及理论框架（图 2)。 


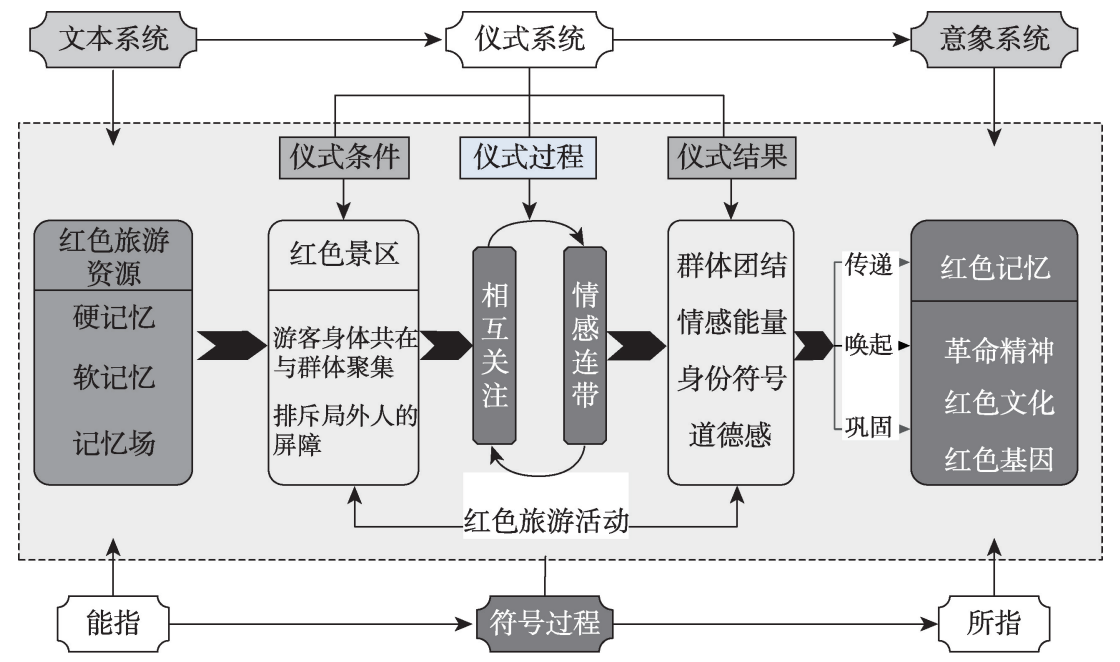

图 2 红色旅游活动传承红色记忆的动态过程模型

Fig. 2 Dynamic process model of red tourism activities passing on red memory

（1）由红色景区的旅游资源（硬记忆和软记忆）构成的记忆之场为红色旅游活动提 供了一个仪式场景，在具备仪式场景的前提下，游客会形成身体共在、群体聚焦和排除 局外人屏障的红色旅游专有仪式情景；（2）在该情景下，游客会将其注意力集中在共同 的红色旅游吸引物上, 形成相互关注, 相互关注让红色旅游景区中的游客知道彼此的所 做所感, 从而形成情感连带, 而进一步强化相互关注, 相互关注与情感连带过程的不断 重复就构成了成功的红色旅游互动仪式;（3）在该仪式中，游客将得到高效的情感能 量, 进而得到群体团结、身份符号和道德感的结果, 红色记忆在游客成功的互动仪式中 被建构和内化, 红色记忆得到传递、唤起和巩固;（4）红色记忆的成功建构和内化又会 增加个体红色旅游参与动机, 强化相互关注与情感连带的过程, 最终形成一个正反馈系 统; (5) 由于游客的个体差异、旅游参与方式差异等因素, 红色旅游活动的互动仪式过 程和结果也会存在差异，而这些差异也将影响红色记忆的传承。

\section{4 结论与讨论}

\section{1 结论}

长久以来, 与红色旅游在实践领域蓬勃发展不一致的是, 红色旅游相关的基础理论 研究相对缺乏, 更多的红色旅游研究集中在对策研究和管理实践方面。尽管从红色旅游 发展来看, 这些研究也具有重要意义, 但受制于探讨问题的理论深度, 此类研究更多地 停留在就事论事的层面, 无法从一般意义上对红色旅游的发展做出指导, 也无益于全面 深刻地认识红色旅游发展中出现的问题和现象。

本文借助文化记忆理论和互动仪式链理论, 尝试对红色旅游传承红色记忆的理论逻 辑和动态过程进行深人的理论探讨, 以期能为红色旅游的基础理论研究做出贡献。在具 体的理论分析中, 首先论证了红色记忆的文化记忆属性, 明确了红色记忆是一种文化记 忆, 之后运用文化记忆理论分析红色记忆传承的基本规律, 在此基础上, 结合红色记忆 的特殊性, 明确了仪式系统在传递、唤起和巩固红色记忆的重要作用。其次, 通过分析 
红色旅游活动作为一种仪式的合理性, 提出了红色旅游活动传承红色记忆的理论逻辑, 证明了红色旅游作为红色记忆传承手段的理论 “合法性”。再次, 考虑到红色旅游活动的 互动性, 在互动仪式链理论的基础上, 提出了红色旅游活动传递、唤起和巩固红色记忆 的动态过程模型, 该模型从理论上阐释了作为仪式的红色旅游活动传承红色记忆的具体 过程。从研究结果来看, 文化记忆理论和互动仪式链理论, 为红色旅游与红色记忆之间 的关系研究提供了广阔的理论空间和丰富的理论细节。通过这两个理论的运用, 让我们 有机会从更一般的视角和更深层次上认识红色旅游在传承红色记忆中的内在逻辑和具体 过程。但必须承认的是, 上述理论逻辑和过程模型均基于理论推导, 还缺乏必要的经验 研究证据, 因此未来的研究重点将通过实证和案例研究对其进行验证和修正。

此外，根据本文提出的理论逻辑，红色旅游的专有仪式情景是仪式展开的必要条 件，仪式情景中的软记忆和硬记忆共同构成了一个记忆之场; 在红色旅游景区规划开发 中，如何在现有旅游资源的基础上，充分发掘可用的软记忆和硬记忆，并将二者相互融 合与互动, 是红色旅游规划开发实践要关注的重点问题。根据动态过程模型, 只有高度 的相互关注与情感连带才能带来成功的仪式结果, 红色旅游景区如何组织游客、管理游 客、引导游客以实现游客之间的高度相互关注与情感连带, 是旅游景区管理实践要关注 的核心问题。总的来看, 红色旅游规划开发工作的要点是打造红色旅游专有仪式情景, 红色旅游景区管理工作的要点是有效地推动游客的相互关注与情感连带。

\section{2 讨论}

鉴于本文所提出的理论模型是对红色旅游传承红色记忆的理论逻辑与动态过程的基 础研究, 因此有必要在该理论模型的基础上, 对红色旅游与红色记忆相关的基础问题展 开讨论, 以使本文的结论与已有研究结论建立联系, 并融人现存的知识网络。结合前文 提出的理论模型, 对以下红色旅游与红色记忆问题展开讨论：(1) 相对于其他旅游类 型, 红色旅游的独特性体现在什么地方?（2）红色旅游作为传承红色记忆的方式之一, 与其他方式 (节庆活动、纪念活动等) 相比, 其独特价值在哪里? (3) 红色旅游传承红 色记忆的作用边界在哪里? (4) 红色旅游融合发展作为近些年红色旅游实践和可持续发 展的新方向, 其理论依据在哪里?

\subsection{1 红色旅游的独特性}

从本文提出的理论逻辑和动态过程模型来看, 相对于其他旅游类型, 红色旅游具有 显著的独特性。与其他的旅游活动不同的是, 红色旅游的文本系统和意象系统是被高度 规定的, 因此在涉及到红色旅游相关的文本系统和意象系统时, 一般旅游的研究结论需 要谨慎应用。作为传承红色记忆重要手段的红色旅游, 其本身与政治权力实践高度相 关，任何违背权力逻辑的红色旅游实践都将失去合法性。红色旅游的发展目的存在鲜明 的特性，红色旅游存在的目的是传承红色记忆，为身份认同和政党认同提供支持。因 此, 红色旅游的独特性主要体现在, 其文本系统和意象系统的高度规定性、与政治权力 实践的高度相关性，以及其为身份认同和政党认同提供支持的功能性。

\subsection{2 作为自然仪式的红色旅游活动}

柯林斯 ${ }^{[40)}$ 将程序化的活动称作正式仪式，将没有正式定型的活动称为自然仪式。自然 仪式是一种自发的仪式，这种自发的仪式提供了更为灵活的成员身份感，更为重要的是 这些自然形成的关注焦点与共享情感在最初的时刻都非常有效, 因为它们有高度的相互 
关注和共享情感[40]。就红色旅游活动而言, 由于其大多时候是一种自发行为, 属于典型的 戈夫曼所列举的日常社交类互动仪式，其灵活的形式和自由的组织方式都决定了它是一 种自然仪式，与其他形式的红色记忆传承形式（比如节庆仪式、纪念仪式）相比, 红色 旅游活动由于其自然仪式的性质，它更容易成功，在传承红色记忆方面具有天然优势。

\subsection{3 成功的仪式与失败的仪式}

柯林斯 ${ }^{[00]}$ 指出, 失败的仪式产生较低的情感能量, 其仪式结果是缺少或没有群体团 结感、缺乏对群体符号的尊重。柯林斯 ${ }^{[40}$ 进一步指出, 造成仪式失败的原因是共同关注 点的缺失和共同的主动情感的缺失。由于游客的个体差异、旅游参与方式差异等因素, 红色旅游活动的互动仪式过程和结果也会存在差异, 其相互关注与情感连带强度必然存 在差异, 尽管作为自然仪式的红色旅游活动具有更高的成功概率, 但并不意味着它一定 是成功的。只有高度相互关注和情感连带的红色旅游活动才能有效地传递、唤起和巩固 红色记忆, 相互关注与情感连带高度依赖于具体的红色旅游专有仪式情景。

\subsection{4 红色旅游与其他旅游形式融合发展作为一种“干扰”机制}

作为仪式系统的红色旅游活动是由符号构成的符号系统, 文化符号可以被看作一个 代码系统, 随着时间的流失, 任何文化符号的代码都可能发生僵化, 并失去其阐释世界 的功能 ${ }^{[22]}$; 但这种情况是可以避免的，当两种代码被使用于同一场景中, “干扰” 就会发 生, 从而补偿或抵消原中心代码的僵化倾向 ${ }^{[2]}$ 。可以将红色旅游活动视为中心代码, 而 将与其融合的其他旅游活动（比如乡村旅游、生态旅游、现代观光农业等）视为 “干 扰” 代码，通过红色旅游与农业旅游、工业旅游相融合的方式 ${ }^{[41-43]}$, 形成 “干扰机制”, 抵消红色旅游活动作为仪式系统可能的僵化趋势, 从而实现红色旅游的可持续发展。

\section{参考文献(References):}

[1] 梁银湘. 红色记忆与巩固中国共产党执政基础研究. 广西社会科学, 2015, (7): 1-6. [LIANG Y X. A study on red memory and consolidation of the ruling base of the Communist Party of China. Guangxi Social Science, 2015, (7): 1-6.]

[2] 龙柏林, 潘丽文. 文化整合的红色记忆维度. 南京社会科学, 2018, (4): 128-136. [LONG B L, PAN L W. The red memory dimension of cultural integration. Nanjing Social Science, 2018, (4): 128-136.]

[3] 梁柱. 历史虚无主义思潮的泛起、特点及其主要表现. 马克思主义研究, 2013, (10): 120-128. [LIANG Z. The rise and characteristics of historical nihilism and its main manifestations. Marxist Studies, 2013, (10): 120-128.]

[4] 刘建平, 伍先福, 黄玲. 红色旅游的三大功能. 学习导报, 2005, (5): 19-21. [LIU J P, WU X F, HUANG L. The three functions of red tourism. Study Guide, 2005, (5): 19-21.]

[5] 阎友兵, 陈非文, 方世敏, 等. 2009年全国红色旅游发展现状调查与思考. 湘潭大学学报: 哲学社会科学版, 2009, 33 (6): 84-84. [YAN Y B, CHEN F W, FANG S M, et al. 2009 National red tourism development status survey and reflection. Journal of Xiangtan University: Philosophy and Social Science Edition, 2009, 33(6): 84-84.]

[6] 方世敏, 陈攀, 曹红春. 免费开放背景下红色旅游景区发展的关键因素研究: 基于湖南花明楼、韶山景区的实地调研 报告. 华东经济管理, 2010, (8): 151-154. [FANG S M, CHEN P, CAO H C. Research on the key factors of red tourism scenic area development under the background of free opening: A field research report based on Hunan Huaminglou and Shaoshan Scenic Areas. East China Economic Management, 2010, (8): 151-154.]

[7] 吕胜男.乡村振兴背景下红色旅游的教育功能与辐射效应. 社会科学家, 2019, (8): 88-94. [LYU S N. The educational function and radiation effect of red tourism in the context of rural revitalization. Social Scientist, 2019, (8): 88-94.]

[8] 刘利琼, 乔旋. 红色旅游的文化价值及育人功能: 以红旗渠为例. 社会科学家, 2020, 276(4): 65-69. [LIU L Q, QIAO $\mathrm{X}$. The cultural value and nurturing function of red tourism: Red Flag Ditch as an example. Social Scientist, 2020, 276 (4): 65-69.]

[9] 高楠, 张新成, 王琳艳. 中国红色旅游网络关注度时空特征及影响因素. 自然资源学报, 2020, 35(5): 1068-1089. 
[GAO N, ZHANG X C, WANG L Y. Spatio-temporal characteristics and influencing factors of Chinese red tourism network attention. Journal of Natural Resources, 2020, 35(5): 1068-1089.]

[10] 王振杰, 张贵星. 构建"红色记忆"传承的常态化机制. 人民论坛, 2018, (8): 134-135. [WANG Z J, ZHANG G X. Building a regular mechanism for the transmission of "red memory". People's Forum, 2018, (8): 134-135.]

[11] 高月, 翟光勇. 纪念空间的转型对红色记忆的书写与传承影响. 广西社会科学, 2020, (6): 131-136. [GAO Y, ZHAI G Y. The impact of the transformation of memorial space on the writing and transmission of red memory. Guangxi Social Science, 2020, (6): 131-136.]

[12] 梁化奎. 红色记忆在中央苏区的多层建构和集体共享. 甘肃社会科学, 2017, (3): 102-106. [LIANG H K. Multi-layered construction and collective sharing of red memory in the Central Soviet Union. Gansu Social Science, 2017, (3): 102-106.]

[13] 徐克帅. 红色旅游和社会记忆. 旅游学刊, 2016, 31(3): 35-42. [XU K S. Red tourism and social memory. Tourism Tribune, 2016, 31(3): 35-42.]

[14] 龙念. 革命历史剧: 集体记忆的影像建构. 湖南大学学报: 社会科学版, 2013, 27(3): 88-91. [LONG N. Revolutionary historical drama: The image construction of collective memory. Journal of Hunan University: Social Science Edition, 2013, 27(3): 88-91.]

[15] 陈莉莉. 优良传统和革命精神的集体记忆研究. 毛泽东邓小平理论研究, 2015, (11): 44-51. [CHEN L L. A study on the collective memory of superior tradition and revolutionary spirit. Study on MAO Zedong and DENG Xiaoping Theories, 2015, (11): 44-51.]

[16] 梁银湘. 后革命时期红色记忆再生产与执政安全研究. 广西社会科学, 2017, (8): 6-10. [LIANG Y X. A study on the reproduction of red memory and ruling security in the post-revolutionary period. Guangxi Social Science, 2017, (8): 6-10.]

[17] 王鹏. 新媒体语境下历史文化集体记忆的建构. 青年记者, 2017, (30): 40-41. [WANG P. The construction of collective memory of history and culture in the context of new media. Young Journalists, 2017, (30): 40-41.]

[18] [德]阿莱达·阿斯曼 著. 潘璐 译. 回忆空间: 文化记忆的形式和变迁. 北京: 北京大学出版社, 2016: 12. [ASMANN A, Translated by PAN L. Memories of Space: Forms and Changes of Cultural Memory. Beijing: Peking University Press, 2016: 12.]

[19] 王蜜. 文化记忆: 兴起逻辑、基本维度和媒介制约. 国外理论动态, 2016, (6): 8-17. [WANG M. Cultural memory: Emergence logic, basic dimensions and media constraints. Foreign Theoretical Dynamics, 2016, (6): 8-17.]

[20] 刘慧梅, 姚源源. 书写、场域与认同: 我国近二十年文化记忆研究综述. 浙江大学学报: 人文社会科学版, 2018, 48 (4): 185-203. [LIU H M, YAO Y Y. Writing, field and identity: A review of cultural memory research in China in the past two decades. Journal of Zhejiang University: Humanities and Social Sciences Edition, 2018, 48(4): 185-203.]

[21] 简 - 奥斯曼, 陶东风. 集体记忆与文化身份. 文化研究, 2011, (0): 3-10. [ASMANN J, TAO D F. Collective memory and cultural identity. Cultural Studies, 2011,(0): 3-10.]

[22] [德]安斯加·纽宁, 维拉·钮宁 著. 闵志荣 译. 文化学研究导论: 理论基础·方法思路·研究视角. 南京: 南京大学出版 社, 2018. [NEUNING A, NEUNING V. Translated by MIN Z Y. Introduction to Cultural Studies: Theoretical Foundations - Methodological Ideas - Research Perspectives. Nanjing: Nanjing University Press, 2018.]

[23] 王霄冰. 文字、仪式与文化记忆. 江西社会科学, 2007, (2): 237-244. [WANG X B. Text, ritual and cultural memory. Jiangxi Social Science, 2007, (2): 237-244.]

[24] 扬・阿斯曼, 管小其. 交往记忆与文化记忆. 学术交流, 2017, (1): 10-15. [ASSMANN J, GUAN X Q. Communicative memory and cultural memory. Academic Exchange, 2017, (1): 10-15.]

[25] 白凯, 康晓媛, 王博林. 延安城市居民红色记忆的建构路径与代际差异. 自然资源学报, 2021, 36(7): 1631-1646. [BAI K, KANG X Y, WANG B L. Construction path and intergenerational differences of Yan'an urban residents' red memory. Journal of Natural Resources, 2021, 36(7): 1631-1646.]

[26] 徐巍. 图像时代的后红色记忆与奇观叙事. 电影艺术, 2015, (3): 75-80. [XU W. Post-red memory and spectacle narrative in the image era. Film Art, 2015, (3): 75-80.]

[27] 黄景春. 当代红色歌谣及其社会记忆: 以湘鄂西地区红色歌谣为主线. 民族文学研究, 2017, 35(3): 31-37. [HUANG J C. Contemporary red songs and their social memory: Taking the red songs in West Xiang-E Region as the main line. Ethnic Literature Research, 2017, 35(3): 31-37.] 
[28] 左冰. 红色旅游与政党认同: 基于井冈山景区的实证研究. 旅游学刊, 2014, 29(9): 60-72. [ZUO B. Red tourism and political party identity: An empirical study based on Jinggang Mountain Scenic Area. Journal of Tourism, 2014, 29(9): 60-72.]

[29] 张圆刚, 刘鲁. 红色旅游资源地游客国家认同的影响因素与多元路径研究: 基于模糊集定性比较分析. 自然资源学: 报, 2021, 36(7): 1658-1672. [ZHANG Y G, LIU L. Research on the influencing factors of national identity of red tourism resource destination from the perspective of configuration and multiple paths: Based on the fuzzy-set qualitative comparative analysis. Journal of Natural Resources, 2021, 36(7): 1658-1672.]

[30] 吕龙, 黄震方, 李东晔. 乡村文化记忆资源的“文一旅”协同评价模型与应用: 以苏州金庭镇为例. 自然资源学报, 2020, 35(7): 1570-1585. [LYU L, HUANG Z F, LI D Y. Establishment and application of "culture-tourism" synergies assessment model of rural cultural memory resources: A case study of Jinting town in Suzhou. Journal of Natural Resources, 2020, 35(7): 1570-1585.]

[31] 扬·阿斯曼, 陈国战. 什么是“文化记忆”?. 国外理论动态, 2016, (6): 18-26. [ASSMANN J, CHEN G Z. What is "cultural memory"?. Foreign Theoretical Dynamics, 2016, (6): 18-26.]

[32] 黄华新, 陈宗明. 符号学导论. 上海: 东方出版中心, 2016: 1-3. [HUANG H X, CHEN Z M. Introduction to Semiotics. Shanghai: Oriental Publishing Center, 2016: 1-3.]

[33] 亚历山大·埃特金德, 张佑慈. 文化记忆中的硬记忆与软记忆: 俄罗斯与德国的政治悼念. 国外理论动态, 2016, (6): 38-46. [ETKIND A, ZHANG Y C. Hard and soft memories in cultural memory: Political mourning in Russia and Germany. Foreign Theoretical Dynamics, 2016, (6): 38-46.]

[34] 赵红梅. 论仪式理论在旅游研究中的应用: 兼评纳尔什・格雷本教授的“旅游仪式论”. 旅游学刊, 2007, (9): 70-74. [ZHAO H M. On the application of ritual theory in tourism research: A review of Professor Narshe Grayburn's "Ritual Theory of Tourism". Journal of Tourism, 2007, (9): 70-74.]

[35] 张进福. 作为仪式的旅游. 世界民族, 2013, (5): 41-53. [ZHANG J F. Tourism as ritual. World Peoples, 2013, (5): 41-53.]

[36] 谢彦君, 徐英. 旅游场中的互动仪式: 旅游体验情感能量的动力学分析. 旅游科学, 2016, 30(1): 1-15. [XIE Y J, XU Y. Interactive rituals in tourism field: A dynamics analysis of the emotional energy of tourism experience. Tourism Science, 2016, 30(1): 1-15.]

[37] 严星雨, 杨效忠. 旅游仪式感特征及其对旅游目的地管理的影响研究. 旅游学刊, 2020, 35(9): 104-112. [YAN X Y, YANG X Z. Research on the characteristics of tourism ritual and its influence on tourism destination management. Journal of Tourism, 2020, 35(9): 104-112.]

[38] XU K. Types of red tourists in China: Evidence from Shaoshan. Annals of Tourism Research, 2015, 51: 57-58.

[39] STERCHELE D. Memorable tourism experiences and their consequences: An interaction ritual (IR) theory approach. Annals of Tourism Research, 2020, 81: 1-13.

[40] (美)兰德尔・柯林斯, 著. 林聚任 等 译. 互动仪式链. 北京: 商务印书馆, 2012. [COLLINS R. Translated by LIN J R, et al. Interactive Ritual Chains. Beijing: The Commercial Press, 2012.]

[41] 阎友兵, 殷韵洁. 韶山全国红色旅游融合发展示范区旅游业融合发展研究. 湖南财政经济学院学报, 2015, 31(3): 102-107. [YAN Y B, YIN Y J. Research on tourism integration development in Shaoshan national red tourism integration development demonstration area. Journal of Hunan College of Finance and Economics, 2015, 31(3): 102-107.]

[42] 周易, 方世敏, 赵可. 基于高质量目标的湘西州红色旅游产业融合发展探析. 上海第二工业大学学报, 2019, 36(3): 202-209. [ZHOU Y, FANG S M, ZHAO K. Exploration of red tourism industry integration development in Xiangxi state based on high quality objectives. Journal of Shanghai Second University of Technology, 2019, 36(3): 202-209.]

[43] 周美静, 许春晓. 红色旅游共生发育水平测评指标体系构建与应用: 以韶山为例. 旅游学刊, 2019, 34(9): 127-144. [ZHOU M J, XU C X. Construction and application of index system for measuring the level of symbiotic development of red tourism: Shaoshan as an example. Tourism Tribune, 2019, 34(9): 127-144.] 


\title{
Research on the theoretical logic and dynamic process of red tourism inheriting red memory
}

\author{
LI Wei-fei, FANG Shi-min, YAN You-bing, MA Li-jun \\ (Xiangtan University, Xiangtan 411105, Hunan, China)
}

\begin{abstract}
Red tourism plays an important role in transmitting red memory, but there is a lack of in-depth theoretical discussion on the basic questions of why red tourism can transmit red memory and the specific process of transmitting red memory by red tourism. With the help of cultural memory theory and interactive ritual chain theory, this study attempts to conduct an indepth theoretical discussion on the mechanism of action and dynamic process of red memory inherited by red tourism, in order to contribute to the basic theoretical framework of red tourism. In the specific theoretical analysis, this study firstly argues the cultural memory attribute of red memory, and then uses the cultural memory theory to analyze the basic laws of red memory transmission. On this basis, combined with the special characteristics of red memory, it clarifies the important role of ritual system in transmitting, evoking and consolidating red memory. Secondly, by analyzing the rationality of red tourism activities as a kind of ritual, this study puts forward the theoretical logic of red tourism activities in transmitting red memories, and proves the theoretical "legitimacy" of red tourism as a means of transmitting red memories. Again, considering the interactive nature of red tourism activities, this study puts forward the dynamic process model of red tourism activities in transmitting, evoking and consolidating red memories on the basis of the theory of interactive ritual chain. This model theoretically explains the specific process of red tourism activities as rituals to transmit, evoke and consolidate red memories. From the research results, cultural memory theory and interactive ritual chain theory, provide a broad theoretical exploration and rich theoretical details for the study of the relationship between red tourism and red memory, and through the application of these two theories, we have a bettter understanding of the inner logic and specific process of red tourism in transmitting red memory from a more general perspective and at a deeper level. However, it must be acknowledged that the above theoretical logic and process models are based on theoretical derivations and still lack the necessary empirical research evidence, so future research will focus on validating and revising them through empirical studies and case studies. The findings of the article help red tourism theoretical researchers understand the relationship between red tourism and red memory from a more universal perspective and at a deeper theoretical level, and provide basic theoretical support for better red tourism work in the practical field.
\end{abstract}

Keywords: red memory; red tourism; cultural memory; interactive ceremony 